\title{
COMPARISON OF ADSORPTION BEHAVIOR OF BOVINE SERUM ALBUMIN AND OSTEOPONTIN ON HYDROXYAPATITE AND ALUMINA
}

\author{
Jumpei Hayashi $^{1 *}$, Masakazu Kawashita ${ }^{1}$, Toshiki Miyazaki ${ }^{2}$, Masanobu Kamitakahara $^{3}$, \\ $\mathrm{Koji} \mathrm{Ioku}^{4}$, Hiroyasu Kanetaka ${ }^{5}$ \\ (*Corresponding author: baya@ecei.tohoku.ac.jp) \\ ${ }^{1}$ Graduate School of Biomedical Engineering, Tohoku University, 6-6-11 Aramaki Aoba, Aoba-ku, Sendai \\ 980-8579 Japan. \\ ${ }^{2}$ Graduate School of Life Science and Systems Engineering, Kyushu Institute of Technology, 2-4 Hibikino, \\ Wakamatsu-ku, Kitakyushu 808-0196 Japan. \\ ${ }^{3}$ Graduate School of Environmental Studies, Tohoku University, 6-6-20 Aramaki Aoba, Aoba-ku, Sendai \\ 980-8579 Japan. \\ ${ }^{4}$ Faculty of Economics, Keio University, 4-1-1 Hiyoshi, Kohoku-ku, Yokohama 223-8521 Japan \\ ${ }^{5}$ Liaison Center for Innovative Dentistry, Graduate School of Dentistry, Tohoku University, 4-1 Seiryo, \\ Aoba-ku, Sendai 980-8575 Japan.
}

Keywords: osteoconductivity, hydroxyapatite, alumina, albumin, osteopontin

Abstract: Adsorption behavior of bovine serum albumin (BSA) and osteopontin (OPN) on osteoconductive hydroxyapatite (HA) and non-osteoconductive alpha-type alumina $\left(\alpha-\mathrm{Al}_{2} \mathrm{O}_{3}\right)$ was studied as function of protein concentration and $\mathrm{pH}$, using Bradford dye binding assay. BSA showed a much larger binding capacity on $\alpha-\mathrm{Al}_{2} \mathrm{O}_{3}$ than that on HA irrespective of BSA solution concentration and $\mathrm{pH}$. Furthermore, OPN is likely to show the same adsorption characteristic as BSA. Definite correlation was not observed between the albumin or OPN adsorption capacity and the osteoconductivity of materials, suggesting that other factors (e.g., orientation, arrangement, etc. of albumin and/or OPN) likely govern expression of the osteoconductivity.

(Received February 2, 2012; Accepted March 30, 2012)

\section{INTRODUCTION}

It is well known that osteoconductivity is the ability of biomaterials to conduct bone formation and to form a chemical bond to bone. The osteoconductive mechanism was considered to progress in six stages: (1) serum protein adsorption, (2) cell recruitment, (3) cell attachment and proliferation, (4) cell differentiation and activation (5) matrix calcification, and finally (6) bone remodeling. ${ }^{1,}$ 2 Therefore, immediately after implantation of biomaterials, the biomaterials are coated by an adsorbed layer of protein in blood and tissue fluids, and the subsequent cellular response are dependent on the proteins adsorbed by the implant surfaces, especially at early interaction times. ${ }^{3,}{ }^{4}$ However, a detailed mechanism of the osteoconductive has not yet been clarified completely.

Hydroxyapatite (HA, $\left.\mathrm{Ca}_{10}\left(\mathrm{PO}_{4}\right)_{6}(\mathrm{OH})_{2}\right)$-based biomaterials are widely used in bone and dental tissue engineering due to their outstanding properties including biocompatibility, bioactivity, and osteoconductivity. ${ }^{5,6}$ HA has two crystal faces: the a-face and the c-face. The a-face has positively charged sites, composed of two screw-axis calcium
$\left(\mathrm{Ca}^{2+}\right)$ ions, in contrast the c-face has negatively charged sites, and connected to the oxygen ions belonging to the three phosphate groups $\left(\mathrm{PO}_{4}^{3{ }^{3-}}\right){ }^{7,8}$

Albumin is the most abundant protein in the circulatory system, ${ }^{9}$ and possesses a high content of charged amino acids such as aspartic and glutamic acids, lysine, and arginine. ${ }^{10}$ Aspartic and glutamic acids can be charged negatively by the deprotonation of $\mathrm{COOH}$ groups whereas lysine and arginine are able to carry a positive charge by protonation of $\mathrm{NH}_{2}$ and guanidino groups, respectively. ${ }^{11}$ Therefore, the great affinity of albumin to HA could be explained by the presence of charged residues that can bind to $\mathrm{Ca}^{2+}$ and $\mathrm{PO}_{4}{ }^{3-}$ sites on HA surface. ${ }^{12}$ Furthermore, albumin is commonly applied for blocking the adsorption of other proteins and to prevent the nonspecific adhesion of cells to diverse artificial substrata, ${ }^{13,14}$ but previous studies suggested that heat denatured bovine serum albumin (BSA) influences the adhesion and proliferation of osteoblast cells to HA. ${ }^{15,16}$ Incidentally, it is generally assumed that the structure and functions of BSA are very similar to those of human serum albumin (HSA) because $76 \%$ of the sequence of BSA is identical to that of HSA. ${ }^{17}$

On the other hand, osteopontin (OPN) is often 
found to be rich at bone-implant interface, ${ }^{1,18}$ and contains one sequence of contiguous aspartic acid residues and an arginine-glycine-aspartic acid (RGD) motif. ${ }^{19}$ OPN binds to HA via the region consisting of nine consecutive aspartic acid residues. The RGD motif mediates cell binding with a number of transmembrane integrin pairs through direct interaction. ${ }^{20}$ Therefore, it has been inferred that OPN mediates the initial recognition of osteoclasts and osteoblasts, subsequent attachment of these cells onto the bone surfaces, and their functions including bone resorption and osteogenesis. $^{21-25}$

On the basis of the above findings, it is suggested that albumin and OPN may play an important role on the expression of osteoconductivity. However, to our knowledge, few works have been done to clarify the differences in the adsorption behaviors of albumin and OPN on osteoconductive and non-osteoconductive materials. Therefore, in this study, we attempted to investigate the adsorption behaviors of albumin and OPN on osteoconductive $\mathrm{HA}$ in comparison with that on non-osteoconductive alpha-type alumina $\left(\alpha-\mathrm{Al}_{2} \mathrm{O}_{3}\right){ }^{6}$

\section{MATERIALS AND METHODS}

\section{1) Materials characterization}

Commercially available HA powder (HAP-200, Taihei Chemical Industrial Co. Ltd., Osaka, Japan) and $\alpha-\mathrm{Al}_{2} \mathrm{O}_{3}$ powder (Kojundo Chemical Lab. Co. Ltd., Saitama, Japan) were used in this study. The crystalline phase was examined with a powder X-ray diffractometer (XRD; RINT-2200VL, Rigaku Co. Ltd., Tokyo, Japan) using the following settings: $\mathrm{X}$-ray source, Ni-filtered $\mathrm{CuK} \alpha$ radiation; X-ray power, $40 \mathrm{kV}, 40 \mathrm{~mA}$; scanning rate, $2 \theta=2 \% / \mathrm{min}$; and sampling angle, $0.02^{\circ}$. The size and shape of the particles were observed using a scanning electron microscope (SEM; VE-8800, Keyence, Tokyo, Japan). Specific surface area (SSA) was determined by nitrogen absorption using BET technique (Autosorb-iQ, Quantachrome Instruments, Florida, USA). ${ }^{26}$ The zeta-potentials of samples and BSA in saline with $\mathrm{pH}$ ranged from 4.0 to 7.4 were measured using laser electrophoresis spectroscopy (ELS-Z, Otsuka Electronics Co. Ltd., Osaka, Japan. and Zetasizer Nano ZS90, Malvern Instruments Ltd., Worcestershire, UK). The $\mathrm{pH}$ was controlled by titration of $10 \mathrm{mM} \mathrm{NaOH}$ or $\mathrm{HCl}$.

\section{2) BSA adsorption measurements}

For each experimental adsorption measurement, commercially available BSA (Jackson Immuno Research Laboratories, Inc., West Grove, USA) was dissolved in saline. Tubes containing $18 \mathrm{mg}$ of HA and $100 \mathrm{mg}$ of $\alpha-\mathrm{Al}_{2} \mathrm{O}_{3}$ were incubated with $1.2 \mathrm{ml}$ and $5 \mathrm{ml}$ of BSA solution respectively, and rotated at $20 \mathrm{rpm}$ at $36.5^{\circ} \mathrm{C}$. The mixture was centrifuged for 5 min at $6000 \mathrm{rpm}$, and then the protein concentration of the supernate was determined using the Bradford dye binding assay. ${ }^{27}$ A control test was set up with BSA in tube at the given BSA concentration without adding $\mathrm{HA}$ or $\alpha-\mathrm{Al}_{2} \mathrm{O}_{3}$ to determine the protein losses in the system, and revealed that these values had variation within $10 \%$.

\section{3) OPN adsorption measurements}

This experiment was conducted as a preliminary experiment owing to the limited amount of OPN available in this study. The OPN adsorption assay was similar to the BSA adsorption test, with some exceptions. In this assay, commercially available OPN (Recombinant Human Osteopontin, R\&D Systems, Inc., Minneapolis, USA) was dissolved in saline with $\mathrm{pH}$ 7.4. Tubes containing $1.8 \mathrm{mg}$ of $\mathrm{HA}$, and $10 \mathrm{mg}$ of $\alpha-\mathrm{Al}_{2} \mathrm{O}_{3}$ were incubated with $0.2 \mathrm{ml}$ and $0.7 \mathrm{ml}$ of OPN solution respectively, and rotated at $20 \mathrm{rpm}$ at $36.5^{\circ} \mathrm{C}$ for $1 \mathrm{~h}$. Subsequent processes were performed like the previously described method.

\section{RESULTS AND DISCUSSION}

FIGURE 1 shows the XRD patterns of (a) HA and (b) $\alpha-\mathrm{Al}_{2} \mathrm{O}_{3}$. It gave diffraction patterns assigned to only $\mathrm{HA}$ and $\alpha-\mathrm{Al}_{2} \mathrm{O}_{3}$. We confirmed that no other unexpected crystalline phase was contained in these samples.

(a)
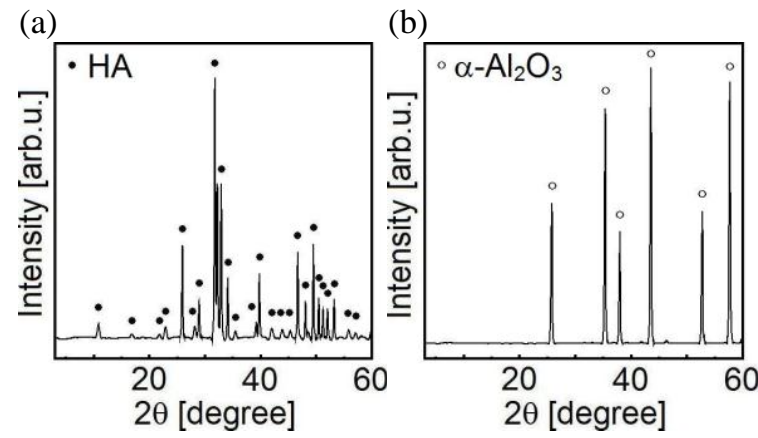

FIGURE 1 XRD patterns of (a) $\mathrm{HA}$ and (b) $\alpha-\mathrm{Al}_{2} \mathrm{O}_{3}$ used in this study

FIGURE 2 shows SEM photographs of (a) HA and (b) $\alpha-\mathrm{Al}_{2} \mathrm{O}_{3}$. Each of the powders was composed of very fine particles that formed agglomerates and short chains. The agglomerates of $\mathrm{HA}$ and $\alpha-\mathrm{Al}_{2} \mathrm{O}_{3}$ had size distribution ranging from 5 to $20 \mu \mathrm{m}$ and from 1 to $20 \mu \mathrm{m}$, respectively, indicating that the present powders had similar size distributions.

TABLE 1 shows the SSAs and zeta potentials of the HA, $\alpha-\mathrm{Al}_{2} \mathrm{O}_{3}$ and BSA, respectively. From SSA data, we can estimate that surface area of $18 \mathrm{mg}$ of $\mathrm{HA}$ is about $0.17 \mathrm{~m}^{2}$, which is comparative to that of $100 \mathrm{mg}$ of $\alpha-\mathrm{Al}_{2} \mathrm{O}_{3}$. From zeta potential data, $\alpha-\mathrm{Al}_{2} \mathrm{O}_{3}$ was positively charged over the examined 
$\mathrm{pH}$ range. In contrast, at high $\mathrm{pH}$ values, $\mathrm{HA}$ and BSA were negatively charged.

FIGURE 3 shows the time-dependent adsorption characteristic of BSA on $\mathrm{HA}$ and $\alpha-\mathrm{Al}_{2} \mathrm{O}_{3}$. Here, the fixed BSA solution concentration and initial $\mathrm{pH}$ were $1.0 \mathrm{mg} / \mathrm{ml}$ and 7.4 , respectively. There was no significant difference in the amount of adsorbed BSA even after incubated for $3 \mathrm{~h}$. In addition, when incubation time exceeded $1 \mathrm{~h}$, some $\alpha-\mathrm{Al}_{2} \mathrm{O}_{3}$ powder agglomerated. Therefore, in the subsequent adsorption experiments, a time period of $1 \mathrm{~h}$ was used.
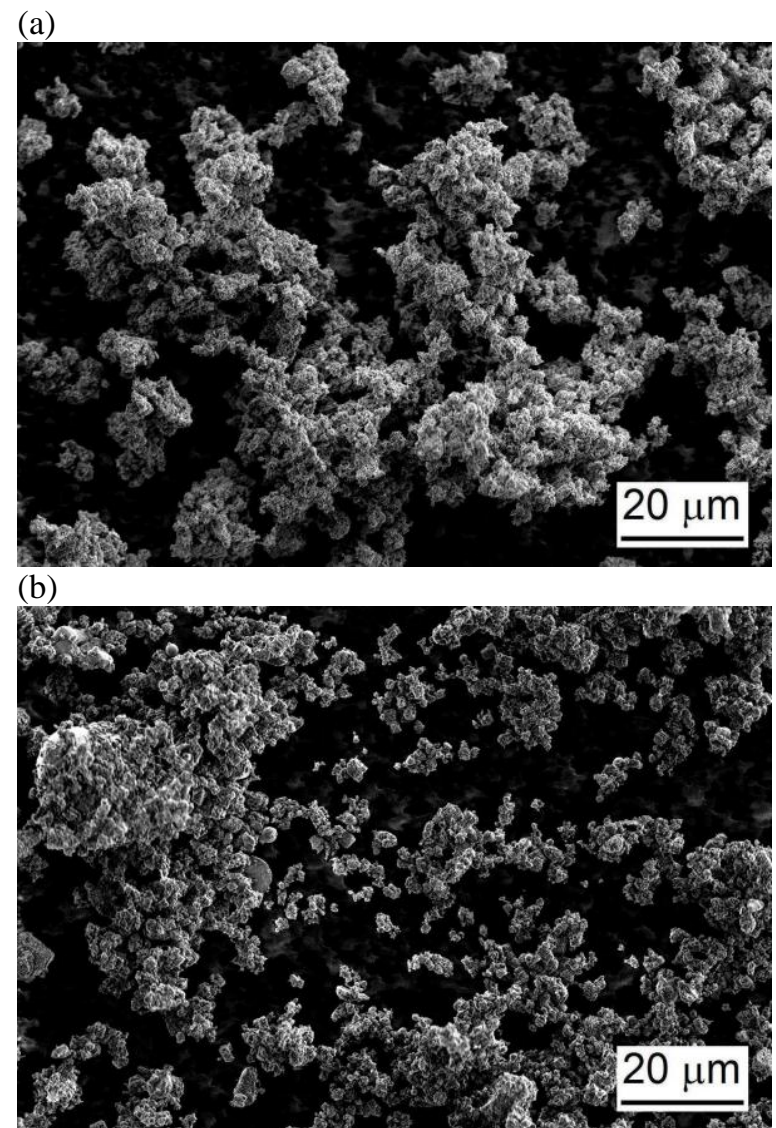

FIGURE 2 SEM photographs of (a) HA and (b) $\alpha-\mathrm{Al}_{2} \mathrm{O}_{3}$

TABLE 1 The specific surface areas (SSAs) and zeta potentials of $\mathrm{HA}, \alpha-\mathrm{Al}_{2} \mathrm{O}_{3}$ and $\mathrm{BSA}$ used in this study

\begin{tabular}{ccccc}
\hline & \multirow{2}{*}{$\begin{array}{c}\text { SSA } \\
{\left[\mathrm{m}^{2} / \mathrm{g}\right]}\end{array}$} & \multicolumn{3}{c}{ Zeta potential $^{*}[\mathrm{mV}]$} \\
\cline { 3 - 5 } & 9.345 & 5.03 & -3.82 & -4.86 \\
\hline $\mathrm{HA}$ & 9.0 & $\mathrm{pH} \mathrm{5.5}$ & $\mathrm{pH} \mathrm{7.4}$ \\
\hline $\mathrm{\alpha}-\mathrm{Al}_{2} \mathrm{O}_{3}$ & 1.685 & 29.7 & 12.3 & 1.09 \\
\hline $\mathrm{BSA}$ & - & 13.0 & -7.83 & -9.80 \\
\hline
\end{tabular}

*Zeta potential was measured in saline.

FIGURE 4 shows the adsorption isotherms of BSA on $\mathrm{HA}$ and $\alpha-\mathrm{Al}_{2} \mathrm{O}_{3}$ at $\mathrm{pH}$ 7.4. The degree of
BSA adsorption to $\mathrm{HA}$ and $\alpha-\mathrm{Al}_{2} \mathrm{O}_{3}$ increased with increasing BSA concentration up to $0.8 \mathrm{mg} / \mathrm{ml}$, and then became almost constant at concentrations higher than $0.8 \mathrm{mg} / \mathrm{ml}$. In other words, the adsorption isotherms of BSA on $\mathrm{HA}$ and $\alpha-\mathrm{Al}_{2} \mathrm{O}_{3}$ are likely to be Langmuir type isotherms indicating monolayer adsorption of chemisorption. ${ }^{28}$

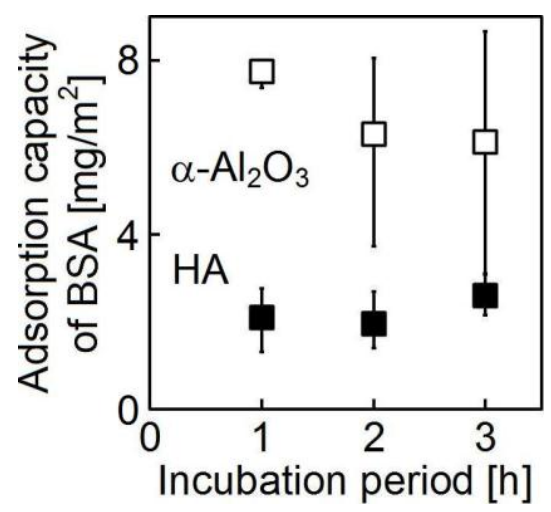

FUGURE 3. Time-dependent adsorption of BSA on $\mathrm{HA}$ and $\alpha-\mathrm{Al}_{2} \mathrm{O}_{3}$

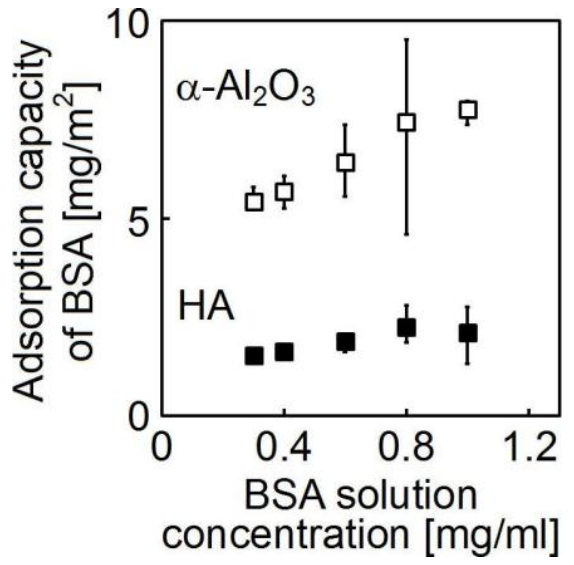

FIGURE 4. Adsorption isotherms of BSA on HA and $\alpha-\mathrm{Al}_{2} \mathrm{O}_{3}$

The equilibrium isotherms for the adsorption of proteins are often described by means of the Langmuir equation, ${ }^{29,30}$ as follows:

$$
q=\frac{\mathrm{K} q_{0} C}{1+\mathrm{K} C}
$$

where $C$ is the equilibrium concentration of the adsorbate, $q$ is the amount of adsorbate adsorbed, $\mathrm{K}$ is the equilibrium constant and $q_{0}$ is the saturation capacity. This equation was transformed into the following equation:

$$
C=-\frac{1}{\mathrm{~K}}+q_{0}\left(\frac{C}{q}\right)
$$

The adsorption data were plotted in the form of $C / q$ 
versus $C$, as shown in FIGURE 5. The square of the correlation coefficients $\left(\mathrm{R}^{2}\right)$ values indicate that the experimental isotherms data of $\alpha-\mathrm{Al}_{2} \mathrm{O}_{3}$ favorably correlated by the Langmuir model.

FIGURE 6 shows adsorption characteristics of BSA on HA and $\alpha-\mathrm{Al}_{2} \mathrm{O}_{3}$ at different $\mathrm{pHs}$. The $\mathrm{pH}$ was controlled by titration of $10 \mathrm{mM} \mathrm{NaOH}$ or $\mathrm{HCl}$. In the measurement, the fixed BSA solution concentration was $1.0 \mathrm{mg} / \mathrm{ml}$. The amount of BSA adsorption on HA slightly decreased with increasing $\mathrm{pH}$. On the other hand, the amount of BSA adsorption on $\alpha-\mathrm{Al}_{2} \mathrm{O}_{3}$ at $\mathrm{pH} 4.0$ was smaller than those at $\mathrm{pHs}$ of 5.5 and 7.4 .

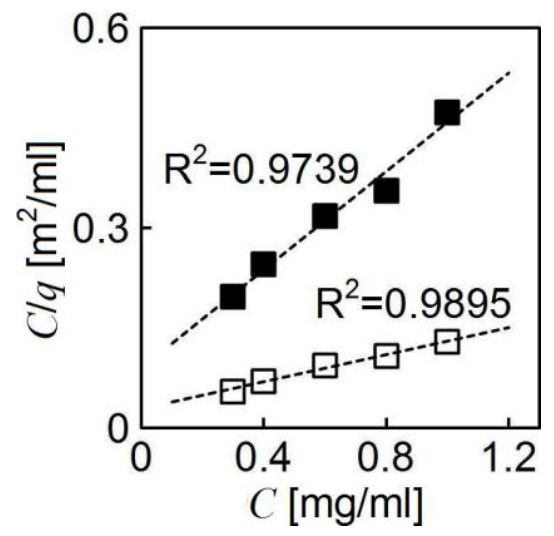

FIGURE 5. The adsorption data plotted as $C / q$ versus $C$ and its linear regression result ( $\mathbf{m} \mathrm{HA}, \square: \alpha-\mathrm{Al}_{2} \mathrm{O}_{3}$, $C$ : BSA solution concentration, $q$ : the amount of adsorbed BSA, $\mathrm{R}^{2}$ : the square of the correlation coefficient)

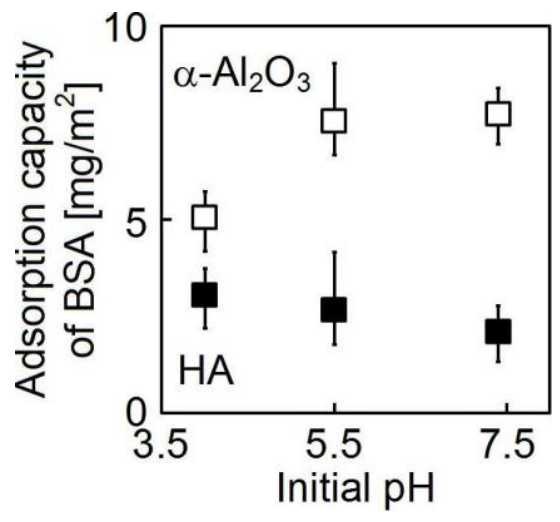

FIGURE 6. Adsorption characteristics of BSA on HA and $\alpha-\mathrm{Al}_{2} \mathrm{O}_{3}$ at different $\mathrm{pH}$

From the above results, BSA showed a much larger binding capacity on $\alpha-\mathrm{Al}_{2} \mathrm{O}_{3}$ than that on $\mathrm{HA}$ (FIGURE 4). Furthermore, this tendency was also observed under different initial pHs (FIGURE 6). This difference could be attributed to the different characteristics of $\mathrm{HA}$ and $\alpha-\mathrm{Al}_{2} \mathrm{O}_{3}$ in TABLE 1 . BSA is a well-characterized protein with the molecular weight of $69 \mathrm{kDa}$, dimensions of $4 \mathrm{~nm} \times 4 \mathrm{~nm} \times 14$ $\mathrm{nm}^{31}$, and its isoelectric point is about 4.6 in saline, ${ }^{32}$ which was almost coincided with that of BSA used in this study (TABLE 1). Therefore, at between about $\mathrm{pH} 4.6$ and 7.4, electrostatic attraction might play an important role on accelerating the adsorption of negatively charged BSA on positively charged $\alpha-\mathrm{Al}_{2} \mathrm{O}_{3}$ surface. In contrast, when $\mathrm{pH}$ is below 4.6, both $\mathrm{BSA}$ and $\alpha-\mathrm{Al}_{2} \mathrm{O}_{3}$ are positively charged and cause the electrostatic repulsion. On the other hand, adsorption of BSA on HA could be due to ionic interaction between amino acids residues with $\mathrm{COO}^{-}$ groups in BSA and the $\mathrm{Ca}^{2+}$ sites on the surface of HA. In solution with high $\mathrm{pH}$ around 7.4, the a-face is captured with $\mathrm{OH}^{-}$ions and as a result, the amount of BSA adsorption is decreased, whereas, the decrease of $\mathrm{OH}^{-}$ions (at low $\mathrm{pH}$ around 4.0) causes an increment in the BSA adsorption.

Human OPN is composed of 314 amino acids with a predicted molecular weight of $32.9 \mathrm{kDa}$, and negatively charged at resulting from the preponderance of acidic amino acids and the multiple serine phosphorylations. ${ }^{33-35}$ Therefore, adsorption mechanism of OPN on HA and $\alpha-\mathrm{Al}_{2} \mathrm{O}_{3}$ could be similar to that of BSA on $\mathrm{HA}$ and $\alpha-\mathrm{Al}_{2} \mathrm{O}_{3}$. FIGURE 7 shows the binding capacity of OPN on HA and $\alpha-\mathrm{Al}_{2} \mathrm{O}_{3}$. In the measurement, the fixed OPN solution concentration and initial $\mathrm{pH}$ were $50 \mu \mathrm{g} / \mathrm{ml}$ and 7.4, respectively. It was found from FIGURE 7 that not only BSA but also OPN shows a much larger binding capacity on $\alpha-\mathrm{Al}_{2} \mathrm{O}_{3}$ than that on $\mathrm{HA}$, although the OPN concentration of the supernate in the adsorption measurement for HA was almost zero, suggesting that more amount of OPN might adsorb on HA and hence further work is still needed.

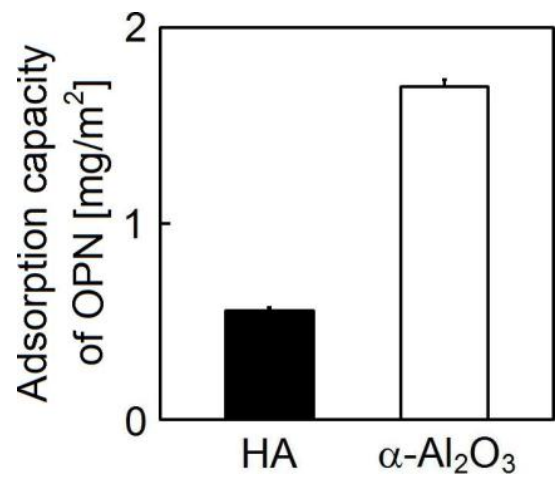

FIGURE 7. The adsorption capacity of OPN on HA and $\alpha-\mathrm{Al}_{2} \mathrm{O}_{3}$

In conclusion, from the results in the present study, correlation was not observed between the albumin or OPN adsorption capacity and the osteoconductivity of materials. It is assumed that not the adsorbed amount but the orientation, arrangement, etc. of albumin or OPN might affects the expression of the osteoconductivity of materials. In order to clarify this hypothesis, further study is in progress to 
investigate the detailed adsorption behaviors of OPN on $\mathrm{HA}$ and $\alpha-\mathrm{Al}_{2} \mathrm{O}_{3}$, and to compare osteoblast adsorption ability on BSA-coated $\mathrm{HA}$ and $\alpha-\mathrm{Al}_{2} \mathrm{O}_{3}$.

\section{CONCLUSIONS}

We examined BSA and OPN adsorption behavior on $\mathrm{HA}$ and $\alpha-\mathrm{Al}_{2} \mathrm{O}_{3}$. Non-osteoconductive $\alpha-\mathrm{Al}_{2} \mathrm{O}_{3}$ showed a much larger BSA adsorption capacity than that of osteoconductive HA. This suggests that other factors (e.g., orientation, arrangement, etc. of albumin and/or OPN) likely govern expression of osteoconductivity.

\section{ACKNOWLEDGEMENT}

The authors thank Mr. Hiroaki Okano and Mr. Fumihiro Kaji, Taihei Chemical Industrial Co. Ltd., for their gratuitous supply of HA powder, and they also thank Prof. Emile H. Ishida, Graduate School of Environmental Studies, Tohoku University, for his kindly support for the use of specific surface area measuring instrument.

\section{REFERENCES}

1. D. A. Puleo, A. Nanci, Biomaterials, 20, 2311 (1999).

2. M. Nakamura, Y. Sekijima, S. Nakamura, T. Kobayashi, K. Niwa, K. Yamashita, J. Biomed. Mater. Res. A, 79 (3), 627 (2006).

3. D. G. Castner, B. D. Ratner, Surf. Sci., 500, 28 (2002).

4. M.Tirrell, E. Kokkoli, M. Biesalski, Surf. Sci., 500, 61 (2002).

5. L. L. Hench, J. Am. Ceram. Soc., 81 (7), 1705 (1998).

6. R. Z. LeGeros, Clin. Orthop. Relat. Res., 395, 81 (2002).

7. T. Kawasaki, S. Takahashi, K. Ikeda, Eur. J. Biochem., 152, 361 (1985).

8. T. Kawasaki, K. Ikeda, S. Takahashi, Y. Kuboki, Eur. J. Biochem., 155, 249 (1986).

9. S. Curry, P. Brick, N. P. Franks, Biochim. Biophys. Acta, 1441, 131 (1999).

10. M. Kawano, J. Hwang, Clay Clay Min., 58 (2), 272 (2010).

11. H. X. Liu, R. S. Zhang, X. J. Yao, M. C. Liu, Z. D. Hu, B. T. Fan, J. Chem. Inf. Comput. Sci., 44, 161 (2004).

12. E. Mavropoulos, A. M. Costa, L. T. Costa, C. A. Achete, A. Mello, J. M. Granjeiro, A. M. Rossi, Colloids Surf. B: Biointerfaces, 83, 1 (2011).
13. L. Liu, S. Chen, C. M. Giachelli, B. D. Ratner, S. Jiang, J. Biomed. Mater. Res. A, 74 (1), 23 (2005).

14. M. T. Bernards, C. Qin, B. D. Ratner, S. Jiang, J. Biomed. Mater. Res. A, 86 (3), 779 (2008).

15. Y. U. Kim, R. Z. LeGeros, K. N. Kim, Y. K. Lee, Mater. Sci. Forum, 539-543 (1), 731 (2007).

16. M. T. Bernards, C. Qin, S. Jiang, Colloids Surf. B: Biointerfaces, 64, 236 (2008).

17. H. M. Kowalczynska, M. Nowak-Wyrzykowska, A. A. Szczepankiewicz, J. Dobkowski, M. Dyda, J. Kaminski, R. Kołos, Colloids Surf. B: Biointerfaces, 84, 536 (2011).

18. Y. Ayukawa, F. Takeshita, T. Inoue, M. Yoshinari, M. Shimono, T. Suetsugu, T. Tanaka, J. Biomed. Mater. Res., 41 (1), 111 (1998).

19. J. Sodek, B. Ganss, M.D. McKee, Crit. Rev. Oral Biol. Med., 11, 279 (2000).

20. M. C. Siebers, P. J. ter Brugge, X. F. Walboomers, J. A. Jansen, Biomaterials, 26, 137 (2005).

21. H. Yoshitake, S. Rittling, D. T. Denhardt, M. Noda, Proc. Natl. Acad. Sci. USA, 96, 8156 (1999).

22. M. Ishijima, S. R. Rittling, T. Yamashita, K. Tsuji, H. Kurosawa, Akira Nifuji, D. T. Denhardt, M. Noda, J. Exp. Med., 193, 399 (2001).

23. H. Kojima, T. Uede, T. Uemura, J. Biochem., 136, 377 (2004).

24. C. L. Duvall, W. R. Taylor, D. Weiss, A. M. Wojtowicz, R. E. Guldberg, J. Bone Miner. Res., 22 (2), 286 (2007).

25. A. Franzen, K. Hultenby, F. P. Reinholt, P. Onnerfjord, D. Heinegard, J. Orthop. Res., 26 (5), 721 (2008).

26. S. Brunauer, P. H. Emmett, E. Teller, J. Am. Chem. Soc., 60, 309 (1938).

27. M. M. Bradford, Anal. Biochem., 72, 248 (1976).

28. I. Langmuir, J. Am. Chem. Soc., 40, 1361 (1918).

29. M. Hamid, M-N. Mohsen, A. Leila, Iran. J. Chem. Chem. Eng., 29 (4), 125 (2010).

30. A. D-Pirouz, N. Kolman, A. Arpanaei, T. Jensen, M. Foss, J. Chevallier, P. Kingshott, J. Baas, K. Søballe, F. Besenbacher, Mater. Sci. Eng. C, 31, 514 (2011)

31. Y. I. Tarasevich, Theor. Exp. Chem., 37 (2), 98 (2001).

32. A. Salis, M. Bostr€om, L. Medda, F. Cugia, B. Barse, D. F. Parsons, B. W. Ninham, M. Monduzzi, Langmuir, 27 (18), 11597 (2011).

33. C. C. Kazanecki, D. J. Uzwiak, D. T. Denhardt, J. 
Cell. Biochem., 102, 912 (2007).

34. A. H-Hernandez, J. G-Morales, A. B. R-Navarro, J. Gautron, Y. Nys, and J. M. G-Ruiz, Cryst. Growth Des., 8 (12), 4330 (2008).
35. P. V. Azzopardi1, J. O’Young, G. Lajoie, M. Karttunen, H. A. Goldberg, G. K. Hunter, Plos One, 5 (2), 9330 (2010) 